\title{
Regulating Risk-Taking by Mutual Funds
}

Mutual funds ${ }^{\mathrm{I}}$ are subject to stricter controls on the use of two important investment techniques-leveraging ${ }^{2}$ and short selling ${ }^{3}$-than most other investors. ${ }^{4}$ In establishing the controls, Congress and the Securities and Exchange Commission (SEC) evidently intended to place limits on the degree of risk ${ }^{5}$ to which mutual funds could subject themselves. The controls, however, are misconceived. They do not, in fact, place a ceiling on risk-taking. Rather, they serve simply to cripple the

1. Mutual funds, like investment companies in general, are corporations that manage the investments of their shareholders by buying and selling stcurities. Unlike some other investment companies, their shares are not traded in any securities market but may be redeemed by the investor at any time for the value at the time of redemption. Because their shares may be redeemed, they are referred to as open-end management companies. They are at present the largest segment of the investment company industry. See SEC, Public Policy Implications of Investaient Comipani Growti, H.R. Rep. Nó. 2337, 89th Cong., 2d Sess. $41-47$ (1966) [hereinafter cited as Compasy Growtu REromt.

2. An investment is "leveraged" when it is purchased with borrowed funds; securities are commonly used as collateral.

3. A "short sale" is an investment technique used to profit from a decline in a security's price. Stock is borrowed from 3 broker and an obligation is incurred to return it within a specified amount of time. The stock is sold immediately, and repurchased within the specified period. The short sale is closed when the stock is returned. A profit is made if the price of the borrowed stock declines between the sale and repurchase. The short seller must pay any dividends that the stock pays while the short sale is open. See P. Samuelson, Economics 401 (8th ed. 1970); D. Hester \& J. Todix, Risk Aversion and Portfolio Choice 41-42 (1967) [hereinafter cited as Hester \& Tonis].

4. Certain institutional investors other than mutual funds are subject to such controls. For instance, insurance companies, pension trusts, and trusteed portfolios are limited in the riskiness of the securities they may acquire. The policy behind these regulations is that these institutions should provide a guaranteed low risk and return rather than provide access to high risk/high return investments. Sce Note, The Regulation of Risky Investments, 83 HARv. L. REv. 603-16 (1970); note 5 infro. Presumably, these same rules on degree of risk would be interpreted to prevent such institutions from leveraging and short selling. However, mutual funds differ in that their purpose is to give the small investor who desires to take risks effective access to the high risl/high return investments of the securities markets, provided that the level of risk a fund proposes to take is revealed to investors. The law does not prevent funds from purchasing high risk securities, but does restrict their use of leverage and short selling. Sec p. 1312 infra.

5. The term "risk" refers to variance in the return on a given insestment. It is the dispersion of less likely outcomes around a most likely outcome. In investment is deemed riskless if a given level of return is guaranted; an investment becomes increasingly risky as the chances increase that the return will differ from the cxpected value. See $J$. WiLlIAMSON, INVESTMENTS: NEW ANALYTIC TEchiniQues 26.32 (1971) [hereinafter cited as J. Williamsox, Techniques]; Joyce \& Vogel, The Unectlainly in Risl: Is I'ariance Unambiguous?, 25 J. FiNANCE 127, 127-28, 131 (1970).

Leverage will increase risk by increasing the rolatility of an investment's return. For example, an investor with net assets of 100 invested in securities will lose ten in a ten percent price decline and gain ten in a ten percent price rise. If he borrows fifty he will increase both his loss and gain to fifteen, minus, of coursc, interest costs. See J. Williamson, Technigues 106-08; Sharpe, A Simplified Arodel for Portfolio Analysis, 9 Management Science 277 (1963).

Some minor qualifications to the definition of risk can be found in W. SILARPE, PORTfolio Theory and Capital Markets 25.26 (1970); D. Farrar, Tue Investuent Decision UNDER UNCERTAINTY 2 (1965). 
funds' performance ${ }^{6}$ capabilities, forcing them to take larger risks than would otherwise be necessary to achieve a given return. The special controls should therefore be withdrawn, and mutual funds given access to leverage and short selling on a par with other investors.

\section{Unequal Access to Leverage and Short Selling}

The securities acts contain a double layer of provisions controlling access to leverage and short selling. First, the Securities and Exchange Act of $1934^{7}$ contains provisions affecting all investors. The Investment Company Act of $1940^{8}$ then sets forth further restrictions applicable only to mutual funds. The Company Act controls, in turn, are supplemented by provisions in the Internal Revenue Code. ${ }^{0}$ The result is that mutual funds are more restricted than other investors in the use of leverage and short selling. ${ }^{10}$

\section{A. Leverage}

\section{The Exchange Act}

The Exchange Act ${ }^{11}$ gives the Federal Reserve Board (FRB) authority to promulgate regulations controlling the maximum amount of credit that lenders may extend for the purpose of buying or carrying securities. The FRB has varied the maximum according to its assessment of economic conditions, generally raising the maximum to encourage economic expansion and lowering it to achieve the contrary. ${ }^{12}$

6. The term "performance" refers to risk-adjusted return. Normally an investor can achieve higher returns by taking higher risks. Therefore, one investor can accurately be said to outperform another only if he achieves higher returns for the same risk level. See SEC, 2 Institutional Investor Study Rerort, H.R. Doc. No. 92.64, 92d Cong., 1st Sess. 325-28 (1971) [hereinafter cited as INSTITUTIONAL StUdY].

7. 15 U.S.C. $\$ \$ 78 \mathrm{a}-78 \mathrm{hh}$ (1970) [hereinafter referred to as the Exchange Act].

8. 15 U.S.C. $\$ \$ 80 \mathrm{a}-1$ to -52 (1970) [hereinafter referred to as the Company $\Lambda \mathrm{ct}$ ].

9. See p. 1310 infra.

10. Leverage and short selling have cconomic equivalents in, respectivcly, calls (options to buy stock) and puts (options to sell stock). To the extent that mutual funds are able to use puts and calls, they can in effect circumvent any limitations on leverage and short selling. Although the SEC has promulgated no express limitations on the acquisition of puts and calls, it appears from an examination of prospectuses and from statements by SEC officials that a ten percent of net assets limitation has becn enforced by the SEC in approving prospectuses of mutual funds. Telephone Interview with staff of the SEC, Washington, D.C., March 16, 1973. The individual officials interviewed requested that their names be kept confidential. A record of the interview is on file with the Yale Law Journal. See, e.g., Prospectus of the Heritage Fund, Inc., April 16, 1971 , at 8.

11. 15 U.S.C. $\$ 78(\mathrm{~g})(1970)$.

12. The rate set by the $F R B$ is stated in terms of margin, that is, the percentage of the value of a security that an investor must deposit in order to buy it. The percentage of a security's value which can be borrowed can be obtained by subtracting 
The FRB regulations, however, contain a number of loopholes which make the effective maximum level of credit an investor may obtain much higher than the nominal maximum set by the FRB. ${ }^{13}$ First, since the credit controls on domestic lenders other than brokers, and on all foreign lenders, apply only to loans using securities as collateral, these lenders may make unsecured loans in unlimited amounts even if the borrower's purpose is to purchase securities. ${ }^{24}$

Second, even if a loan does use securities as collateral, limits on credit advanced by lenders other than brokers apply only if the purpose of the loan is to purchase or carry securities, and the term "purpose" has been interpreted broadly enough so that, in certain situations, borrowing by individuals can clearly exceed the nominal limits. ${ }^{25}$

Third, the FRB has exercised its authority only over the initial purchase of securities, not over the carrying of securities. ${ }^{10}$ Therefore, if securities are purchased with the maximum amount of credit allowed by FRB rules, and their value declines so that the amount of the loan surpasses that permitted by law, no additional payment will be required. ${ }^{17}$

the margin rate from 100 . Thus, if the current margin rate is sixty. an investor may borrow no more than forty percent of the purchase price of a security. I table listing the various rates in force from 1934 to July 28,1960 , can be found in the Excrctorasis of Banking and Finance 431 (1961). Data for July 28, 1960, to present can be found in FRB Reg. T, 12 C.F.R. \$ 220.8c (1960.72); 2 CCH FED. SEC. L. KEP. ( 22,230 (1973).

13. In the years before 1973, the loopholes were even more numerous. The FRB has only gradually extended the coverage of its regulations over the full range of pos. sible lenders, leaving the others open as sources of unregulated credit. Brokers, dealers, and members of registered securities exchanges were covercd by Regulation $T$ in 1934 . See Solomon \& Hart, Recent Developments in the Regulation of Securities Credit, 20 J. PUB. LAw 167, 171-72 (1971). Banks making loans for the purchase or carring of securities were covered by Regulation $U$ in 1936. See id. at 171-72. FRB Reg. U presently is codified at 12 C.F.R. $\$ 221$ (1972). Other lenders were covered by kegulation $G$ in 1968. See Solomon \& Hart, supra, at 183.84. FRB Reg. G presently is codified at 12 C.F.R. $\$ 207$ (1972). Finally, foreign lenders were covered by Regulation $X$ in 1971. See Solomon \& Hart, supra, at 202-11. FRB Reg. $X$ presently is codified at 12 C.F.R. $\S 224(19 \pi 2)$.

Also, the FRB has permitted different lenders to make loans on different clases of securities. For instance, those lenders covered by Regulation $T$ vicre, until I969, permitted to make loans only on securities listed on a registered securities exchange. As of 1969 , they were permitted to make loans on certain desiguated nonlisted securities. Solomon \& Hart, supra, at 168. Other lenders, including banks, while presently able to make loans on over-the-counter (OTC) stock only to the extent permitted lenders covered by Regulation $T$, were able before 1969 to make unrestricted loans on OTC stock. The pre-1969 rules are summarized in 4 SEC, SPECIal. STUdy of tIIE Secunmes MIARKETS, H.R. Doc. No. 95, 88th Cong., 1st Sess., 15-35 (1963) [hereinafter cited as SPECIAL STudy]; the post-1969 rules are contained in FRB Reg. G, 12 C.F.R. \$ 207.2(I) (1972), and FRB Reg. U, 12 C.F.R. \$221.I(a)(1) (1972).

14. See Solomon \& Hart, supra note 13 , at 211 .

15. FRB Reg. U, 12 C.F.R. $\$ 221.1(a)$ (1972); FRB Reg. G, 12 C.F.R. \$ 207.1(c) (1972); FRB Reg. X, 12 C.F.R. $\$ 224.2(\mathrm{~b})$ (1972). FRB Reg. $T$, which coicrs lending by brokers and dealers, does not contain such a non-purpose exception.

16. See 4 SPECLAL Study, supra note 13 , at 5.

17. See Solomon and Hart, supra note 13, at 172-73. The absence of an SEC re. quirement for a minimum margin for carrying securities is to some extent countered by the fact that the margin is measured not with respect to cach individual security pur- 
Fourth, no credit limit at all is imposed on the purchase of sccurities used in bona fide arbitrage operations-transactions where securities are sold between markets or bought with rights to convert or exchange them for other securities within a specified time period. ${ }^{18}$

And fifth, investors may borrow beyond the nominal credit limits by pyramiding their investments. For example, an investment partnership may obtain credit up to FRB limits on its portfolio. An individual partner may then borrow up to FRB limits on his interest in the partnership. He thereby obtains double leverage on one portfolio of securities. ${ }^{19}$

\section{The Company Act}

The Company $\mathrm{Act}^{20}$ prohibits mutual funds from borrowing from brokers unless the SEC establishes rules sanctioning and regulating the practice. It also forbids funds from borrowing through the issuance of senior securities, and permits borrowing from banks only to the extent that assets are always at least 300 percent of borrowing. ${ }^{21}$

Under SEC rules, the funds may borrow only from banks, not from brokers or any other lender. ${ }^{22}$ The amount borrowed may be included in assets for purposes of the 300 percent asset coverage requirement. ${ }^{23}$ As a result, the 300 percent requirement in effect allows a mutual fund to borrow up to one-third of the value of its securities. ${ }^{24}$ Finally, a

chased but rather with respect to a borrower's aggregate indebtedness to a particular Iender. Therefore, provided there are new loans made on newly purchased securities to a particular lender, the minimum margins on purchase become minimum margins on carrying securities, since any disparity with the initial purchase margin creatcd by a fall in the value of securities must be made up before the loan can be extended to purchase a new security. However, this complication can be avoided by opening up an account with a new bank or broker. See FRB Reg. T, 12 C.F.R. $\$ 220.3$ (1972); FRB Reg. U, 12 C.F.R. \$ 221.1(d) (1972); FRB Reg. G, 12 C.F.R. § 207.1(g) (1972); FRB Reg. X, 12 C.F.R. $\$ 224.2(\mathrm{~b})$ (1972).

Stock exchanges, however, ordinarily do prescribe a minimum carrying margin. For the New York Stock Exchange, it is presently twenty-five percent. Rulc 431, NYSE Guide I 2431(b).

18. FRB Reg. T, 12 C.F.R. $\S \S 220.4(\mathrm{~d}), 220.8$ (1972); FRB Reg. U, 12 C.F.R. $\$ 221.2(j)$ (1972); FRB Reg. X, 12 C.F.R. $\$ 224.2(\mathrm{~b})$ (1972). The situation is not specifically covered in FRB Reg. G, 12 C.F.R. $\$ 207$ (1972).

19. Telephone Interview with Patricia Abelle, Division of Security Crcdit Regulation, Federal Reserve Bank of New York, Jan. 30, 1973.

20. Company Act $\$ 12(\mathrm{a})(1), 15$ UU.S.C. $\$ 80 \mathrm{a}-12$ (a)(1) (1970).

21. Company Act $\$ 18(t)(1), 15$ U.S.C. $\$ 80 \mathrm{a}-18(\mathrm{t})(1)(1970)$.

22. SEC Investment Company Act Release No. 7221, at 7 (Junc 9, 1972) [herein. after cited as Company Act Rel. No. 7221]. Prior to the original publication of this position in SEC Investment Company Act Release No. 5634 (March 11, 1969) [herein. after cited as Company Act Rel. No. 5634], the SEC evidently enforced this restriction administratively through its authority to approve and disapprove prospectuses of mutual funds. Telephone Interview with SEC staff, supra note 10.

23. Company Act Rel. No. 5634, supra note 22, at 8; SEC Investment Company Act Release No. 7220, at 9 (June 9, 1972) [hereinafter cited as Company Act Rel, No. 7220].

24. This is true because a fund with net assets of 100 may borrow 50 and still meet the 300 percent rule, since $150=3 \times 50$. The same result is achicved by purchasing shares worth 150 with 100 in net assets at a $66 \%$ percent margin, or allowing an in vestor to borrow one-third of the value of a security. See note 12 supra. 
mutual fund must comply with the Exchange Act credit limitations set by the FRB if they are stricter than the 300 percent rule. ${ }^{25}$

Therefore, ignoring the loopholes in the Exchange Act credit controls, mutual funds are subject to stricter controls whenever the FRB credit regulations allow more borrowing than the 300 percent rule, and to equal controls in all other periods. ${ }^{20}$ The nominal borrowing limit set by the FRB has in fact been more liberal for roughly forty percent of the period from 1940-1973..7

Furthermore, aside from the opportunity for pyramiding-which is of limited usefulness to the typical mutual fund investor since he is unable to take advantage of the significant economies of scale in borrowing ${ }^{28}$-the loopholes in the scheme of regulation set up by the Exchange Act are not paralleled in the Company Act controls. Consequently, the effective credit controls applicable to mutual funds have at all times been stricter than the controls applicable to other investors. ${ }^{29}$

\section{B. Short Sales}

The Exchange Act, in addition to prohibiting short selling of a security when its price is falling, ${ }^{30}$ subjects short sales to the FRB credit controls on normal purchases of securities. ${ }^{31}$

Although the Company Act does not contain any express prohibition on short selling, it does grant the SEC discretion to prescribe limita-

25. Company Act Rel. No. 7220, supra note 23, at 9.

26. At present the FRB maximum is 35 percent, very close to the 3315 percent limitation on mutual funds. For the period $1971-73$ the FRB maximum was 45 percent, far less strict than the $331 / 3$ percent limit. See FRB Reg. T, 12 C.F.R. $\$ 220.8$ (1972); 2 CCH FED. SEC. L. REP. I 22,236 (1973).

27. See note 12 supra.

28. At two brokerage houses, for example, the minimum collateral requirements for opening a margin account were respectively $\$ 2500$ and $\$ 10,000$. In cach case interest rates were on a sliding scale, declining as loan size grew. Telephone Intervieus with representatives of Merrill, Lynch, Pierce, Fenner, \& Smith, and White, Weld \& Co., New York City, January 29, 1973. Banks follow a similar policy. Telephone Intervicw with loan official of Chase Manhattan Bank, January 29, 1973. (The individuals asked that their names be kept confidential. Records of the interviers are on file with the Yale Law Journal.) See Fester \& ToBis, supra note 3, at 41 .

29. See note 12 supra. The FRB tends to relax margin controls when it is pursuing other expansionary policies. Since economic expansions are usually accompanied by rises in prices in the securities markets, increased access to securities credit at such time

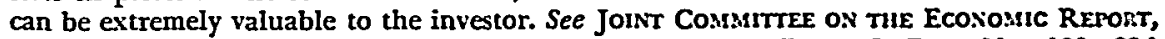
Monetary Policy and the Manageaient of the Public Dent, S. Doc. No. 123, 82d Cong., 2d Sess., 408-12 (1952).

30. The so-called "uptick" rule, 17 C.F.R. $\$ 240.10 \mathrm{a}-1(\mathrm{a})$ (1972). The purpose of the rule is to prevent accentuation of market declines, the theory being that short selling in a market decline will accelerate the decline. See 2 SpEchis. Studr, supra note 13, at 246-50.

31. See FRB Reg. T, 12 C.F.R. $\$ 220.8$ (1972). 
tions. $^{32}$ The SEC has effectively prohibited all borrowing on short sales by mutual funds. ${ }^{33}$

A specific limit on short selling (even without borrowing) to thirtyfive percent of a fund's net assets has been imposed until recently by formal rule. ${ }^{34}$ In the future, the SEC is expected to enforce a similar limitation in the approval of registration statements. ${ }^{35}$ However, even if such an administrative limitation were not enforced by the SEC, the Internal Revenue Code places a severe tax penalty on gains that mutual funds obtain from short selling which would, in all probability, prevent a fund from short selling much more than thirty-five percent of its net assets. $^{36}$

\section{Regulation of Mutual Funds: Goals and Results}

\section{A. The Goals of the Regulatory Scheme}

In passing the Securities Act of $1933^{37}$ and the Exchange Act, Congress sought to improve the securities markets as an investment vehicle for the small investor ${ }^{38}$ by equalizing the flow of information to sophis-

32. Company Act $\$ 12(a)(3)$, 15 U.S.C. $\$ 80 a-12(a)(3)(1970)$.

33. See SEC Investment Company Act Release No. 5633, at 5.6 (March 11, 1969) [hereinafter cited as Company Act Rel. No. 5633]; Company Act Rel. No. 5634, stuprit note 22, at 9.10; Company Act Rel. No. 7221, supra note 22, at 6-7. This limitation is effected by a requirement that mutual funds which sell short maintain at all times in a segregated account, in addition to the proceeds of the short salc, an amount in the form of cash or government securities equal to the difference between the current price of any security sold short and any margin required by the broker who nego. tiated the short sale. This is the equivalent of a 100 percent margin requirement for the purchase and carrying of a security. Presumably, this requirement will limit at mutual fund with net assets of 100 to short sales of less than 100 , since a reserve must be kept to increase the amount in the segregated account in case the price of the shorted stocks should rise. Because of the segregated account requirement, borrowings apparently can not be made using the assets in the segregated account as collateral. However, this point has not been specifically settled. The limitations do not apply to short sales against the box, that is, short sales when the fund contemporancously owns an equivalent amount of the securities shorted. Telephone Interview with SEC staff, supra note 10.

34. Company Act Rel. No. 7221, supra note 22, at 6, 7; Telephone Interview with SEC staff, supra note 10 . The thirty-five percent of net assets restriction was containcd in Company Act Rel. No. 5633, supra note 33, at 5.6.

35. Althongh the thirty-five percent rule was not officially promulgated until 1969, it was enforced administratively before then. As of 1972 the rule was dropped, but the SEC indicates that it may continue to enforce it on the administrative lcvel. Tele. phone Interview with SEC staff, supra note 10.

36. Provisions of the Internal Revenue Code of 1954, as amended [hereinafter re. ferred to as Code], exempt mutual funds from taxation at the corporate level, with the result that shareholders are taxed only once on their fund income. Onc of the conditions of the exemption is that a fund not derive more than thirty percent of its gross income from the sale of securities held for less than three months. See Code \$ 851(b). The gains derived from short selling will almost certainly be of stuch a short term nature. See Code $\$ 1233$ and corresponding Treasury Regulations; Prscrising LAW INSTITUTE, TAX CoNSEQUENCES OF INVESTMENTS 7-28 (1969).

The ordinary investor may, of course, short 100 percent of his assets, including bor. rowing, since he need only deposit a margin against each short salc. See FRB Reg. ' $\mathrm{T}$, 12 C.F.R. $\$ 220.3(\mathrm{c})(\mathrm{d})$.

37. 15 U.S.C. $\$ 77 a-77 a a(1970)$ [hereinafter referred to as the Securities Act].

38. Congressional investigations in the early 1930's revealed that an inordinate pro. portion of the gross profits from the securities markets had gone into the pockets of 
ticated and unsophisticated participants in the markets, ${ }^{30}$ by prohibiting the use of certain investment techniques by sophisticated investors, ${ }^{40}$ and by limiting the share of gross investment profits that providers of investment services could claim as compensation. ${ }^{41}$

Passage of the Company Act came in 1940, following an SEC investigation of the mutual fund industry:2 which revealed that large numbers of small investors were still not investing directly in the securities markets because they could not obtain the substantial advantages of diversification ${ }^{43}$ and professional investment management unless they pooled their money in vehicles such as mutual funds. ${ }^{4 t}$ Although mutual funds had been characterized by gross mismanagement and heavy losses, ${ }^{45}$ Congress sought to preserve and regulate the industry so that the small investor could have effective access to high return/high risk securities investments as an alternative to the low guaranteed returns offered him

sophisticated participants such as corporate insiders and brokers. Is a result small, unsophisticated investors had lost confidence in the securities markets, and corporations had lost a potential source of capital. See S. REP. No. 1455. 73d Cong. 2u Sess. (1934).

39. The Securities Act works to equalize the flow of information by requitiring disclosure by companies at the time of issue of their securities. See Securities .Ict SS 5, 6, 7. 10 , 15 U.S.C. $\$ \$ 77(e),(f),(g),(j)(1970) ;$ S. REP. No. $47.73 d$ Cong., lst Sess. 1 para. 2 (1933); H.R. Rer. No. 85, 73d Cong., lst Sess. 3 para. 1 (1933).

The Exchange Act requires disclosure by brokers and dealers and disclosure in the after-market (sales after the original issue) by corporations whose stock is traded on national exchanges. See Exchange Act $\$ \$ 6,12,13,14,15,15.1$, 15 U.S.C. $\$ \$ 78(0)$, (1). (m), (n), (o) (1970); S. REP. No. 792, 73d Cong., 2d Sess. 3 para. 2, at 9 para. 3 (1931). Recent amendments to the Exchange Act vere also designed to equalize the flow of information among investors. See S. REp. No. 379, 88th Cong., Ist Sess. 6 pars. 1-4, at 4 paras. 2, 5 (1963); H.R. REP. No. 1418, 88th Cong., 2d Sess. 4 paras. 1, 5 (1964).

40. Certain investment techniques, such as pooling of sales and purchases and trading on inside information, are especially useful to larger, more sophisticated insestors. The Exchange Act limits the use of such techniques. See Exchange Act \$S 9, 10, 16, 15 U.S.C. $\$ \$ 78(i)$, (j), (p) (1970); S. REP. No. 792, 73d Cong., $2 d$ Sess. 3 para. 2, at 7, 8, 9 (1931); H.R. REP. No. 1383, 73d Cong., 2d Sess. 11 para. 3 (1934).

41. See Exchange Act $\$ 19(\mathrm{~b})(\mathrm{a}), 15$ U.S.C. $\$ 78(\mathrm{~s})(\mathrm{b})(\mathrm{g})(1970)$; sce S. REP. No. 145J, 73d Cong., 2d Sess. (1934). In recent cases the SEC and the courts have also relied upon the securities acts" "equal opportunity goal" in making decisions in technical areas not covered directly by statute. See, e.g., SEC v. Texas Gulf Sulfur, 401 F.2d 833 (2d Cir. 1968) (en banc), cert. denied, 394 U.S. 976 (1969). For an excellent discussion of the equal opportunity goal and its possible limitations in the context of the Securities and Exchange Act of 1934, see A. Bromberc, Securimes Law: Frato-SEC Rule 10b-j $\$ \$ 3.2 \& 12.2(1971)$.

42 See S. REP. No. 1775, 76th Cong, 3d Sess. 4 para. I, at 6 para. 4; 4 SEC. Reront on the Stuny of INvestment Trusts AND Investment CoMpanies 371-73 (1934-42) [hereinafter cited as TRUST STUDY]. It should be noted that ch. VII of pt. 3, as well as pis. 4 \& 5, were not submitted to Congress until after the passage of the Company Act and cannot, therefore, be relied on as legislative history. For a list of dates of delivery of the various parts of the Trust Study, sec Note, Mrutual Fund Control-Transfer Profits: Congress, The SEC, and Rosenfeld v. Black, 58 VA. L. REv. $371,373.74$ n.16 (1972).

43. Diversification refers to the practice of investing a portfolio in a number of different securities rather than in a single security. It can be demonstrated that by so doing an investor can reduce the risk on his investment without correspondingly re. ducing expected return. See note 72 infra.

44. Investment advisors normally require a very large minimum portfolio before they will undertake to manage it. See Hearings on $S$. 3550 Before a Subcomm. on Banking and Currency, 76th Cong., 3d Sess., pt. 2, at 286 (1910) [hereinafter cited as 1940 Senate Hearings].

45. See 4 Trust STudy, supra note 42, at $371-73 ; 3$ id. at 20-23; 1910 Senate Hearings $37-39,788-98$. 
by savings banks and other financial intermediaries. ${ }^{40}$ To repeated objections in the Senate that some controls should be put on the riskiness of securities that a mutual fund could buy, ${ }^{47}$ the SEC replied that the purpose of the Company Act was not to dictate the riskiness of securities to be purchased by a mutual fund as long as the investment policy was disclosed to investors before they purchased shares in the fund.48 The SEC view prevailed, and the Company Act placed no limits on purchases of individual securities according to riskiness, although, to protect small investors, the Act equalized the flow of information between them and more sophisticated participants in the securities markets, ${ }^{49}$ prohibited the use of certain investment techniques, ${ }^{50}$ and controlled the compensation of providers of investment services. ${ }^{b 1}$

Nonetheless, the legislative history indicates that Congress' motivation in approving the leveraging controls was to limit risk. The legislators' theory was apparently that leveraging would accentuate the effect of price movements in market downswings on funds' performance, thereby increasing the danger of bankruptcy. ${ }^{62}$ It was felt that controls on leveraging, unlike limits on purchases of risky securities, would not foreclose the possibility of high returns. The SEC's Trust Study, ${ }^{53}$ which served as the empirical foundation for the Company Act, purported to find a strong correlation for the 1930-1935 market between poor performance by mutual funds and bank debt. ${ }^{\text {bt }}$ Evidently

46. See S. REP. No. 1775 , 76th Cong., 3d Sess. 4 para. 1, at 6 para. 4 , at 11 para. 5 , at 12 para. 1 (1940); H.R. Rer. No. 2639, 76th Cong., 3d Sess. (1940); Company Gnowril REPORT, supra note 1, at 1-3. 1 SPECIAL STUDY, supra note 13, at $369.70 ; 4$ id. at 279.77; Hearings on S. 3580 Before a Subcomm. on Banking and Currency, 76th Cong., 8d Scss., pt. 2, at 286 .

47. See 1940 Senate Hearings, supra note 44, at 233, 286; Hearings on H.R. 10065 Before a Subcomm. of the House Comm. on Interstate and Foreign Commerce, 77th Cong., 3d Sess. 112 (1940) [hereinafter cited as 1940 House Hearings].

48. 1940 Senate Hearings 233 . The SEC now regulates the purchasc of risky securitics in a haphazard and indirect way by preventing mutual funds from having more than ten percent of their assets in illiquid investments-i.e., investments for which thare is no established trading market, such as real estate investments or letter stock which has not been registered with the SEC. See Company Act Rel. No. 7221, supra note 22, at $8 \cdot 10$. Such a restriction does not effectively limit risk-taking since there are many high risk securities traded on the OTC market. See Wall St. J., Jan. 26, 1973, at 1, col. 6. 49. See Company Act $\S \S 1(\mathrm{~b})(1), 8,29,30,15$ U.S.C. $\$ \$ 80 \mathrm{a} \cdot 1(\mathrm{~b})(1),-8,-29,-30$; S. REP. No. 1775, 76th Cong., 3d Sess. 6-8 (1940); H.R. Rep. No. 2639, 76 th Cong., 8d Sess. 8.10 (1940).

50. See Company Act $\S 35,15$ U.S.C. $\$ 80 \mathrm{a}-35$ (1970); S. REP. No. 1775, 76th Cong., 3d Sess. 6, 7, 15 (1940); H.R. REP. No. 2639, 76th Cong., 3d Sess. 8, 9, 26 (1940).

51. See Company Act $\S \S 15,22(\mathrm{~b}), 27(f), 15$ U.S.C. $\$ \S 80 \mathrm{a}-15,-22(\mathrm{~b}), .27(\mathrm{f})(1970)$; H.R. ReP. No. 2639, 76 th Cong., 3d Sess. 8 (1940); S. REr. No. 1775, 76th Cong., 8d Sess. 6, 9 (1940).

52. See 1940 Senate Hearings, supra note 44, at 288, 1027-31; Company Act § 1(b)(7),

15 U.S.C. $\S 80 \mathrm{a}-1(\mathrm{~b})(7)(1970)$.

53. Note 42 supra.

54. The SEC's results on leverage in general, including leverage by issuance of senior securities, bank borrowing, and other forms of borrowing are contained in 2 TRusr STUvY, supra note 42 , at 478-79. Those on bank debt are in 2 Trust STUDY 474, 921-29. The Trust Study results suggested a ranking of the three forms of leveraging in descending order of ill effect: (1) senior securities, (2) bank borrowing, and (3) margin. Sce 2 Tkust STUDY 474, 478-79, 921-23; 3 id. at 1583-94; notes 50-53 supra. 
Congress concluded that leveraging could only cause net losses for mutual fund shareholders.

The Company Act itself did not limit short selling by mutual funds but gave the SEC discretion to do so. ${ }^{55}$ As is apparent from SEC commentary, the limitations actually adopted were intended to limit risk; the SEC's reasoning was that while potential loss on an ordinary purchase of securities is limited to the purchase price of the security, the potential loss on a short sale is unlimited since the security's price may rise indefinitely. ${ }^{56}$ Neither Congress nor the SEC gave any indication that it expected short selling controls to impair a fund's ability to obtain high returns in the securities markets.

\section{B. The Recent Revolt Against the Funds: the Performance Problem}

Throughout the 1940's and 1950's, the system appeared to function admirably as increasing numbers of small investors sought the investment benefits provided by mutual funds. ${ }^{57}$ However, in the 1960 's several studies indicated that the supposed advantages of mutual funds might not be nearly so substantial as had been thought. ${ }^{.8}$ The studies, although differing on specific figures, agreed that the funds generally did not perform better than collections of securities chosen at random. ${ }^{59}$ Moreover, where funds did perform well, the gains were often

55. 15 U.S.C. $\$ 80 \mathrm{a}-12(\mathrm{a})(3)$. In passing the Exchange Act controls on short selling, and presumably also in passing the Company Act controls, Congress' rationale was that short selling accentuated downward price movements, causing margin purchasers to default on their loans and thereby further accentuating the price decline. Short sclling was also associated with trading on the basis of inside information. See S. REP. No. 14j5, 73d Cong., 2d Sess., 50-54 (1934); 2 Special Study, supra note 13, at 246.94.

An SEC study of the role of short selling in the 1962 market break indicated that short selling did accentuate market declines and recommended that the SEC increase the level of its controls. See 2 Srecial Study 246-94. Similar results were reported in Seneca, Short Interest: Bearish or Bullish, 22 J. Finaxce 67 (1967). Another study's results were more indefinite, however. See F. Mlaciulay, SHort Seluiv on tuE New: YoRk STOCK ExchaNGe (1951).

56. See Company Act Rel. No. 7221, supra note 22.

57. See Investament Co. Instrute, Management INvestment Cominies 88.91 (1962); C.F.A. Research foundation, Investament Company portfollo Managesievt xiit-xxi (1970) [hereinafter cited as C.F.A. PortFolio Study].

58. See I. Friend, M. Blume \& J. Crockett, Mutual, funds and Other Institutional INvestors (1970) [hereinafter cited as Friend StUdY]; 2 InstitutionsL Study, supra note 6, at 325-32; Wharton School of Finaxce aNd Cominerce, A Study of Mútual Funid, H.R. REP. No. 2274, 87th Cong., 2d Sess. (1962) [hereinafter citcd as WilastoN Studv]. 59. Wharton Study 17-18; Fruend Study 50.69. A number of earlier studies of mutual fund performance, e.g., Sharpe, Mutual Fund Performance, $1966 \mathrm{~J}$. Bus. 119 (1965): Jenson, The Performance of Mutual Funds in the Period 1945-61, 1968 J. Fivasce 389 (1968); Treynor \& Mazuy, Can Mutual Funds Outguess the Marhet?, Hans. Bus. REv., July-Aug. 1960, at 131, also concluded that mutual funds, before expenses, underperformed unmanaged portfolios or broad market indices, creating the clcar impression that an investor could do as well as the average mutual fund by throwing darts at the stock market page. But see 2 Institutiossl. STudy, supra note 6 , at 325-32, which found a slight tendency for funds on the average to outperform unmanaged portfolios.

The general conclusion of the studies was buttressed by two subsidiary conclusions. First, although funds which invested in riskier assets were able to outperform more conservative funds and sometimes market averages, their superiority tended to disappear 
offset, at least in part, by inordinately high management and transactions costs. ${ }^{60}$

As this information was disseminated, the growth rate of the funds began to slow. ${ }^{61}$ In 1972, the growth rate for the industry as a whole became negative, with net redemptions exceeding purchases by $\$ 1.7$ billion. ${ }^{22}$ Large numbers of investors, especially those willing to take higher risks to achieve higher returns, apparently ceased using mutual funds. ${ }^{63}$

In response, Congress and the SEC sought to improve the funds' performance by reducing the management, selling, and transaction costs of funds. ${ }^{\text {G4 }}$ To date, these measures apparently have had no major effect. ${ }^{\circ 5}$ What has escaped notice so far is that the poor performance of the funds may well be due, at least in part, to the strict controls on leverage and short selling to which the funds have been subjected.

\section{Portfolio Theory and the Stricter Controls on Mutual Funds}

Analysis of the special controls on mutual funds in the light of economic theory indicates that their effects have been quite contrary to those anticipated by Congress: they do not, in fact, place a ceiling on risk-taking; rather, they simply act as a barrier to good performance,

when compared to a randomly chosen portfolio of similar volatility. Friend STUdy 59; 2 InSTITUTIONAL STUDY 325.32. Second, the ability of individual funds to outperform random portfolios in given years also seemed to be a random event. That is, very fow funds seemed to have the ability consistently to outperform random portfolios of the same risk level. Wharton Study 19; 2 Institutional Study 325-32.

60. See V. Brudner \& M. Chireistein, Corporate Finance 1110 (1972).

61. See C.F.A. PortFolio Study, supra note 57, at xxi-xxii. See also Revoll Against the Funds, ForruNe, Dec. 1971, at 165-66. There were, of course, additional reasons for the growth slowdown, the most significant of which was increased competition from other financial intermediaries. It is not possible to allocate any specific portion of the growth slowdown to poor performance, although it almost certainly played a part. See IUUsiness WEEK, March 3, 1973, at 48-52.

62. Wall St. J., Jan. 26, 1973, at 26, col. 3 .

63. See Revolt Against the Funds, FortunE, Dec. 1971, at 165.66. A recent SEC study indicated that the revolt may be confined for the most part to the riskier funds, with the lower risk funds continuing to grow. See N.Y. Times, March 15, 1978, at 63, cols. 4.6; note 4 supra.

64. The Investment Company Act Amendments of 1970, Pub. L. No. 91.547, 84 Stat. 1413 (1970), made changes in the Company Act and the Investment Advisers Act, 15 U.S.C. $\$ 80 \mathrm{~b}-1$ to -21 to give the SEC increased powers over advisory fecs payable by mutual funds and sales fees payable by investors. See Manges, The Investment Company Amendments Act of 1970, 26 Bus. LAw. 1311 (1971); H.R. REP. No. 91-1982, 91st Cong., 2d Sess. (1970); S. Rer. No. 91-184, 9lst Cong., lst Sess. (1969); H.R. REr. No. 91-1631, 91st Cong., $2 d$ Sess. (Conf. 1970); SEC Investment Company Act Relcase No. 6336 (Feb. 2, 1971); Company Growth REPort, supra note 1, at 7.32. The SEC has eliminated fixed brokerage fees on sales and purchases of large blocks of stock. Sec SEC Securities Exchange Act Release No. 9079 (Feb. 11, 1971); 4 INstitutional Stumr, supra note 6, at 2183-84; 5 SPECIAL STUdy, supra note 13, at 171; Note, Conflict of Interest in the Allocation of Mutual Fund Brokerage Business, 80 YALE L.J. 372, 380.81 (1970); Russo \& Wang, The Structure of the Securities Market-Past and Future, 41 FokdinM L. REv. 1 (1972).

65. For the thirteenth consecutive month as of February 1973, net mutual fund redemptions exceeded sales. See Wall St. J., March 22, 1973, at 14, col. 3. But see notc 63 supra. 
forcing mutual funds to take higher risks than would otherwise be necessary to achieve a given return.

\section{A. Portfolio Theory and Efficient Risk Taking}

Economists have developed a body of theory, now widely accepted, which makes it possible to analyze investments in risky assets in terms of efficiency. ${ }^{68}$

The theory is based on four principles. First, it is assumed that individual investors seek to minimize risk and maximize return on investments. ${ }^{67}$ The most efficient investments in risky assets such as stocks will therefore be those which produce the maximum return at each level of risk; all other investments can be dismissed as inefficient because they force an investor to take higher risks than necessary to achieve a given level of return. ${ }^{88}$ Thus, by locating undervalued or overvalued securities-that is, securities on which the market has fixed a mistakenly low or high price given the riskiness they involve-an investor can increase the efficiency of his investments. ${ }^{69}$

Second, if the choice is among efficient securities, a higher return on an investment can normally be obtained only by taking higher risks. ${ }^{\text {T0 }}$

Third, risk is appropriately measured only with respect to an investor's entire portfolio of investments, rather than for each individual security. Thus, a portfolio equally divided between savings bonds and high risk securities might well subject an investor to the same risk level as a portfolio consisting entirely of medium risk securities. ${ }^{71}$ Furthermore, since the prices of the several securities in a portfolio may vary

66. The foundations for portfolio theory are contained in Tobin, Liquidity Preference as Behavior Towards Risk, 25 REv. EcoN. STudies 65 (1958) [hereinafter citcd as Tobin, Liquidity]; H. Markowitz, Portfolio Selection: Efficient Diversification of InVest. MENTS (1959) [hereinafter cited as H. MARkowrtz, PoRtfolios]. Recent desclopinents are summarized in K. SMmth, Portfolio Management (1971): J. Willuasison, Treaisigues, supra note 5 . An easily comprehensible presentation of the basic elements of portfolio theory can be found in Cohen, The Suitability Rule and Economic Theory, 80 Yale L.J. 1604 (1971).

Although there is some debate on the techniques to be used in the actual selection of portfolios under the theory, the broad outlines are accepted without question by cconomists. The debate centers on the measurement of expected return and risk, with some contending that past price movements alone are a useful guide while others contend that such measurements must be combined with subjective estimates of future price movements in order to be meaningful, and still others contend that no cxact measurements of risk and return can be obtained although an investor can get a general picture. See D. Farrar, The Investaient Decision UNDER UINCERTainTY (1965); SMitTI, Pontfolio Management, supra, at 3-7; Friend \& Blume, Measurement of Portfolio Per/ormance under Uncertainty, 60 AM. EcoN. REv. 561, $561-62$ (1970): Jojce \& Vogel, The Uncerlainly in Risk: Is Variance Unambiguous, 25 J. Fisaxce 127, 127-28 (1970); Cohen \& Pogue, An Empirical Evaluation of Alternative Porlfolio-Selection Models, $40 \mathrm{~J}$. Bus. 166 (1907).

67. Empirical evidence of the risk aversion characteristic of investors is contained in Sharpe, Risk-Aversion in the Stock Alarket: Some Empirical Evidence, $20 \mathrm{~J}$. Fivasce 416 (1965); J. WiLliaAison, TECHNIQUEs, supra note 5, at 30.32.

68. See K. Simtr, Portfolio Management, supra note 65, at $71-75$.

69. See K. SMrri, Portfolio Management 96-97. But see note 86 infra.

70. See Sharpe, supra note 67, at 416; Friend \& Blume, supra note 60.

71. See H. Miakroivitz, Portfolios, supra note 66, at 112-15. 
in different directions, or at least at different rates over time, the riskiness of the whole portfolio is typically less than the average riskiness of its securities. The expected return on a whole portfolio, on the other hand, is merely the weighted average of the expected returns on the securities composing it. Therefore, diversifying a portfolio among various securities, instead of investing in only one kind of security, will typically reduce the risk an investor must bear to attain any given expected return on his portfolio. ${ }^{72}$

Through selection of under- and over-valued securities and through diversification, efficient portfolios of risky investments can be constructed at each level of risk. ${ }^{73}$ But a fourth principle of portfolio the-

72. Assume a portfolio consisting of only two stocks. If the rates of return on the stocks are perfectly correlated, the variance (risk) in the portfolio rate of return is the same as the variance for each stock and nothing is gained from combining thein. If there is perfect negative correlation, the variance in the portfolio rate of return is completely eliminated. If the returns on the stocks are completely unrelated, the vari. ance in the portfolio rate of return is only half the variance of each stock alone.

Although perfectly negatively correlated securities are difficult to locatc, sccurities that show less than perfect positive correlation, or no correlation, in their rates of return appear to be fairly common. The overall risk level of a portfolio therefore can be reduced by including within it increasing numbers of securities, and thus increasing the chances that the variance in the rate of return for any given security will be compensated for by the variance in the others. For practical purposes, however, the advantages that can be obtained from diversifying a portfolio in this fashion beyond the point where the portfolio contains roughly twenty securities appear to be negligible. See K. Smith, Portfolio Management, supra note 66, at 126-31; J. Willianison, TechNIQUES, supra note 5, at 120-21; Evans \& Archer, Diversification and the Reduction of Dispersion: An Empirical Analysis, $23 \mathrm{~J}$. Finance 761 (1968); Mao, Essentials of Portfolio Diversification Strategy, $25 \mathrm{~J}$. FINANCE 1109 (1970). The impact of short selling on diversification is discussed in note 82 infra.

73. That is, one can construct an efficiency frontier, as shown in Graph I, which displays, for each level of risk, the maximum expected return that can be obtained by assembling portfolios of risky assets:

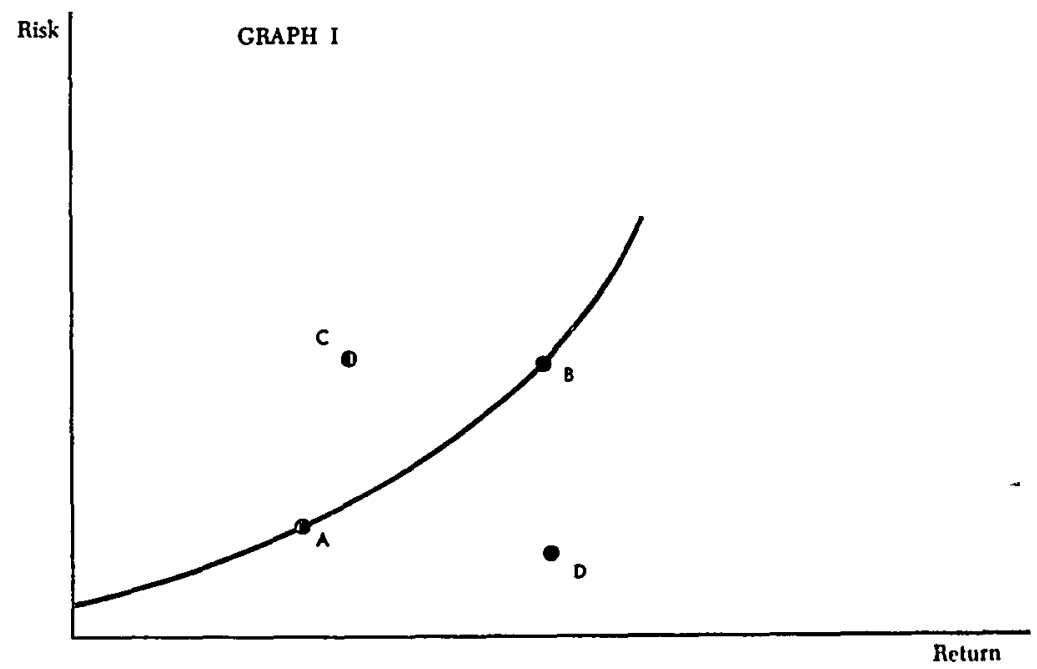

As expected, a higher return can be obtained only by assuming higher risks. Portfollos $A$ and $B$ are both diversified and maximize return at their respective lcvels of risk, $A$ being low risk and $B$ being high risk. Portfolio $C$ is inefficient, either because it is not 
ory, the "separation theorem," holds that, once the possibilities of borrowing and lending are added to the possibility of acquiring risky assets, it will be possible to locate a unique, "most efficient" portfolio of risky assets. This unique portfolio will be the best choice for an investor, regardless of the level of risk he desires. If the investor desires a lower level of risk than that of the unique portfolio, he should place only part of his funds in that portfolio, and place the rest in riskfree investments such as a savings account or United States Savings Bonds. Or, more importantly for the discussion here, if an investor desires a higher risk and return level than that afforded by the unique portfolio, it will be more efficient for him to leverage that portfolio rather than to invest in a different portfolio with a higher risk level. ${ }^{\text {it }}$

diversified or because it includes securities that do not offer maximum return for the level of risk they involve. Portfolio $D$ would be more efficient but there are no risky assets to be purchased which allow an investor to achicve that low a level of risk for that high a return.

The empirical derivation of an efficiency fronticr for the 1961.66 market is demonstrated in K. SMITh, Portfolio Management, supra note 66, at 126-44.

74. In Graph II below, the unique "most efficient" portfolio is portfolio $C$, located at the point where the line $R Q$ is tangent to the frontier of efficient portfolios $S T$, see note 73 supra. Point $R$ gives the return on a risk-free investment. (It is assumed here that the interest rates for borrowing and lending that confront an investor are the same. See infra.)

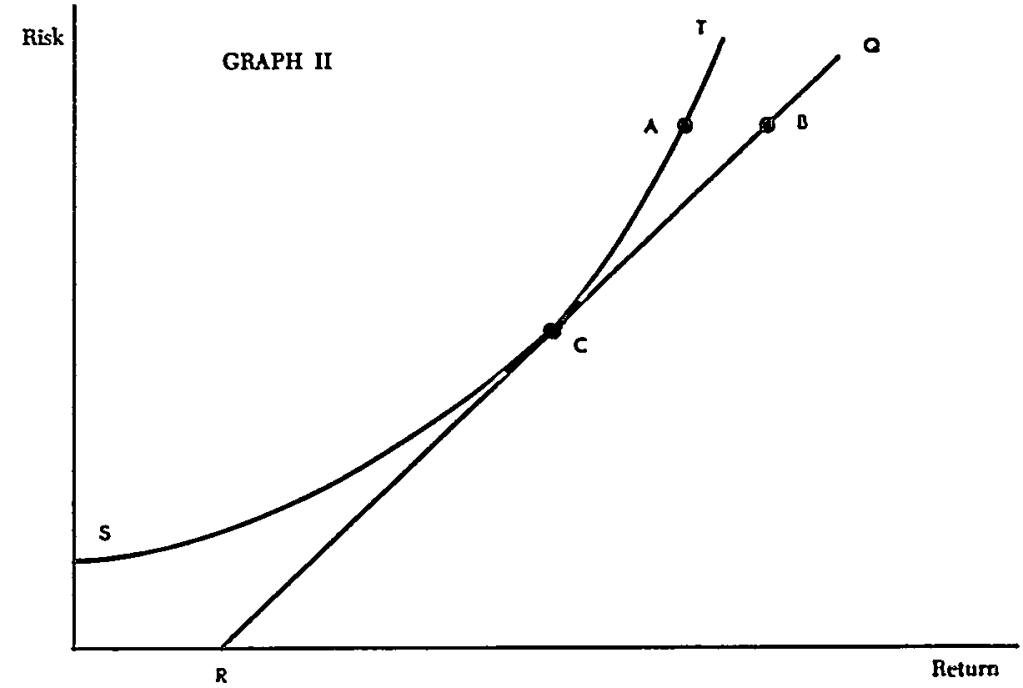

Portfolios along the line $C R$ can be obtained by combining risk-free assets with portfolio $C$, and portfolios along $C Q$ can be oblained by leveraging portiolio $C$. Portfolios $A$ and $B$ are at the same risk Ievel, but portfolio $B$ is obtained by leveraging portfolio $C$ while portfolio $A$ is obtained by simply forming an efficient portolio which contains riskier securities than those contained in portfolio $C$. Portfolio $B$, which gives the higher return of the two, is obviously more efficient.

An explanation of the relative efficiency of leveraging as a means of increasing risk in portfolios at risk levels at or above that of portfolio $C$ is contained in HESTER \& IODIs, supra note 3 , at $45-46$.

This process of selecting the "most efficient" portfolio, according to the so.called separation theorem, does not necessarily imply that the same portfolio of risky securities 
Within this theoretical framework, a mutual fund can enable an investor to make more efficient investments by using superior investment analysis to locate under- and over-valued securities, by diversifying his portfolio, by using riskless investment or leverage (at more attractive interest rates than those available to individuals) in combination with the unique portfolio of risky securities, and by taking advantage of scale economies in advisory and brokerage services. ${ }^{70}$

\section{B. Implications for the Company Act Controls}

Because leveraging and the purchase of higher risk securities are both means of increasing risk and return, the Company Act controls on leveraging do not serve as an effective ceiling on risk-taking; mutual funds remain free to increase the risk level of their portfolios by purchasing higher risk securities. ${ }^{70}$ In fact, the primary effect of the stricter controls on leveraging applied to mutual funds is simply to hurt performance by forcing inefficient risk-taking. Increasing risk by leveraging the unique portfolio is more efficient than increasing risk by acquiring a portfolio of securities of a higher risk level than those making up the unique portfolio. ${ }^{77}$

is best for all investors. One man's best portfolio may differ from another's at any given point in time because of tax considerations, transaction costs, and non-sccurity risky assets. See K. Smith, Portfolio MANAGesient, supra note 66, at 139.40, 209-07. Morcover, even for one given investor, the composition of the best risky portfolio may vary over time as economic conditions change and the securities market reaches new equilibria. See K. SMmt, Portfolio Management 141.49; J. Williamson, Teciniques, supra note 5, at 106-09; B. STONE, Risk, RETURN, AND Equilibrium (1970). The folindation for the determination of a unique solution can be found in Sharpe, $A$ Simplified Model for Portfolio Analysis, 9 MANacement Science 277 (1963). See also Fama, Risk, Return, \& Equilibrium, $79 \mathrm{~J}$. Pox. Econ. 30 (1971). A unique solution is possible, however, only if the borrowing and lending rates are assumed to be equal. If borrowing and lending rates differ, as they normally will, a number of solutions are possible, depending on whether an investor wants to adjust the risk level of his portfolio upward or downward. See J. Williamson, Techniques 106-08.

75. See Sharpe, Mutual Fund Performance, 39 J. Bus. 119, 120 (1966); pp. 1309 \& 1914 supra. By pooling their investments in vehicles such as mutual funds, small investors should be able to take advantage of such economies.

Indeed, there is evidence that many mutual fund investors who arc secking low risk investments are taking advantage of economies of scale by investing in funds specializing in the purchase of corporate bonds available only to large-scale investors. See Wall St. J., Jan. 31, 1973, at 1, col. 6.

76. But see note 48 supra.

77. In terms of Graph II, supra note 74 , the effect of the controls on leveraging is to place a limit on the extent to which a mutual fund can increase risk and return by following line $C Q$; funds seeking higher risk and returns are thus forced to shift to the less efficient strategy of advancing along the frontier $C T$ by purchasing a portfolio containing higher-risk securities than does portfolio $C$.

The margin controls applied to all investors under the Exchange Act have the same general effect, but since they are generally less strict than the controls applicd to mutual funds, see p. 1309 supra, most investors have the advantage of being able to move further along $C Q$ than can mutual funds.

There is some evidence that controls on access of all investors to credit can be bencficial by reducing overall risk levels in the economy. See Economic Poulcy AND THE Regulation of Corporate Securities 206-07 (H. Manne ed. 1969). But see Moore, 
Furthermore, forcing funds to seek higher returns by purchasing high risk securities rather than by leveraging probably increases the danger of bankruptcy. Not only will the purchase of high risk securities needlessly increase the volatility of a fund's portfolio, but in addition such purchases are likely to make the fund's portfolio less liquid, since high risk securities tend to become illiquid in market downturns. ${ }^{78}$ Finally, by limiting the extent to which investors can borrow through the mutual fund vehicle, the controls prevent small investors from taking advantage of economies of scale in borrowing. ${ }^{70}$

The limits on short selling, evaluated as risk controls, are equally unfortunate. Since the price movements of many securities are positively correlated, short selling a substantial fraction of gross assets will probably reduce risk rather than increase it. ${ }^{80}$ If undervalued securities can be located, short selling may be a more efficient means of reducing risk than adding risk-free investments to the most efficient portfolio. ${ }^{81}$

Stock Market Margin Requirements, 74 J. Pot. Ecos. 158 (1960). Indeed, reduction of market volatility was one of the stated reasons for passage of the Exchange Act's controls on securities credit. See Hearings Before the Senate Comm. on Banking and Currency, 73d Cong., lst Sess., pt. 15, at 6496 (1934); 4 SPECIAL. STtDY, supra note 13, at 2.3; 2 id. at $9-15$.

78. See Wall St. J., Jan. 26, 1973, at 1, col. 6. An inability to sell illiquid portfolio investments such as letter stock or very risky over-the-counter stock may very vell render a fund incapable of redeeming the securities of its investors during a period of market decline, thereby forcing it into bankruptcy. Illiquid investments also cannot be sold to cover a margin call in a falling market.

79. See note 28 supra. In terms of Graph Ir, supra note 74, the effect of obtaining lower interest rates for borrowing is to shift line $C Q$ downward to the right, and thus to permit an investor to leverage with even greater efficiency.

80. K. SMirth, PortFolio MaNaGement, supra note 66, at 142-43, provides an cmpirical demonstration for the 1961-66 market showing that short selling approximately forty percent of gross assets would reduce risk.

81. This possibility is illustrated below:

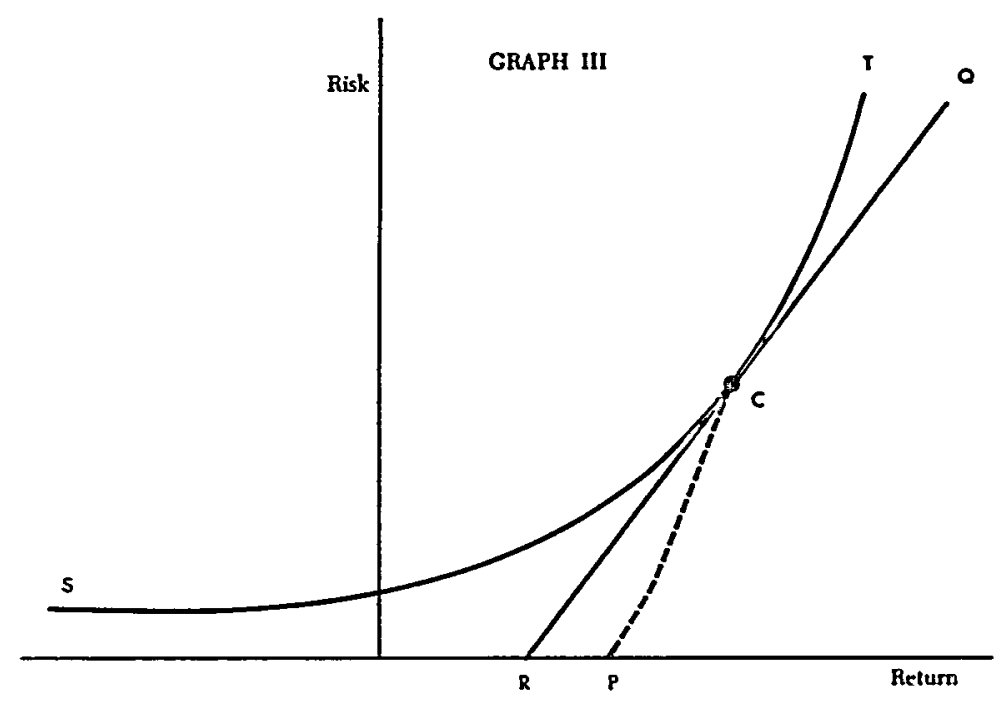


Finally, short selling probably will enable an investor to obtain the benefits of diversification less expensively. ${ }^{82}$

Short selling may also be necessary to purchase the most efficient portfolio. ${ }^{82}$ This will be especially true if a general market downturn can be foreseen. ${ }^{83}$ In such a case, short selling 100 percent of gross assets may be the proper strategy. ${ }^{8+}$ Further, by combining leveraged long purchases of securities with short sales of equivalent investments, investors may also be able to obtain risk-free returns from arbitrage operations. ${ }^{85}$ To the extent that the stricter controls on mutual funds limit the use of short selling, they thus may force the funds to take unnecessary risks. ${ }^{86}$

The usual effect of short selling is to extend the efficiency frontier $S T$ to the left, as shown. See note 74 supra. The shape of the frontier was derived cmpirically in $K$. Smith, Portfolio Management, supra note 66, at 142.43, from data for the 1961.66 market. As expected in a generally rising market, adding short sales up to nearly half of the portfolio will reduce risk, although reducing risk by adding risk-free assets to portfolio $C$ is clearly a more efficient means of risk reduction (that is, reducing risk along $R C$ is more efficient than reducing risk along $S C$ ). However, there is somc cridence that by finding longs and shorts with sufficiently negatively correlated returns, investors may be able to acquire portfolios along $C P$ more efficient than those along CR. See Loomis, The Jones Nobody Keeps $U_{p}$ With, ForTUNE, April 1966, at 297. Mc. Donald \& Baron, Risk and Return on Short Positions in Common Stocks, $28 \mathrm{~J}$. Financk: 97 (1973). But see note 86 infra.

82. See K. Smith, Portfolio Management, supra note 66, at 126-81; Hester \& Toin, supra note 3, at 41-50; note 72 supra; V. Brudney \& M. Chirelstein, Corrorate FinancE
995-98 (1972).

Short selling will enable the investor to add securities with negatively correlated rcturns to his portfolio. This will permit the investor to achieve the optimal bencfits of diversification by holding fewer securities than he would if he could acquire only sccurities with independent or positive covariance. Because he holds fewer securities, his management costs will be lower.

83. If short sales offer a higher return at a given level of risk than normal pur. chases, they will be more efficient investments. See HesTer \& TOBIN, stupra note 8, it 41-50. But see note 86 infra. In a general market downturn the prices of most stocks will be moving downward. It will be more difficult than not in such a situation to find securities whose prices will rise.

84. See K. SMith, Portfolio MANAgement, supra note 66, at 143-44.

85. Empirical studies have shown that securities which should have the same price in the market, such as common stock and bonds convertible into that common stock, or options to buy or sell common stock (calls or puts) and common stock, often do not have equivalent prices because of imperfections in the market. By shorting the overvalued security and purchasing the undervalued one, an investor can make a risk-frec gain. See E. Thorp \& S. Kassouf, Beat THE MARKet: A Scientific Stock Market System (1967) [hereinafter cited as THORP \& KAssour]. Although the SEC's controls on short selling do contain an exception for arbitrage operations, the tax rules do not. See Company Act Rel. No. 7221, supra note 22, at 7; note 36 supra. In addition, the stricter controls on leveraging will prevent a mutual fund from engaging in arbitrage operations to the same extent that other investors can. See pp. 1308 \& 1309 supra.

86. A body of economic theory, the theory of efficient markets, supported by an impressive amount of empirical data, indicates that, because of the speed with which securities prices adapt to new information, it is impossible to find undervalued or overvalued sccurities. See Fama, Efficient Capital Markets: A Review of Theoretical and Empirical Work, $25 \mathrm{~J}$. FinANCE 383 (1970). One would expect that if the efficicnt markets theory is correct, speculative short selling would be unprofitable in a generally rising market such as that of the past twenty years. Such, indecd, is the result of empirical tests of the profitability of short positions. However, even under such a theory, short selling can still be useful for diversification, risk reduction, and risk and non-risk arbitrage purposes. See McDonald \& Baron, supra note 77; note 77 supra; notes $89-91$ infra. 


\section{Empirical Evidence Supporting the Theoretical Conclusions}

These theoretical expectations are supported by empirical evidence, although the data are by no means conclusive.

Since 1950 sophisticated investors have employed a number of investment techniques that depend heavily upon leverage and short selling. These techniques include leveraged long purchases, ${ }^{87}$ pure short selling, ${ }^{88}$ hedging, ${ }^{89}$ convertible arbitrage, ${ }^{90}$ and risk arbitrage. ${ }^{01} \mathrm{Be}$ cause none of the investors specializing in such techniques is subject to disclosure requirements concerning performance, and because none of the securities acts requires "disclosure by technique, complete data on the performance of such investors cannot be readily obtained. No specific data are available on relative risk levels, and so a strict performance comparison cannot be made..$^{22}$ Nonetheless, the available evidence $^{93}$ indicates that investors who are not subject to the strict limita-

87. This technique involves borrowing as much money as is permitted by the margin rules to buy stocks.

88. The term "pure short selling," as used here, refers to short selling in seareh of a profit rather than short selling to reduce risk. See, e.g., Looking for Losers-Short Seller Berman Strikes Gold Picking Stocks on the Way Down, Wall St. J., Jan. 23, 1970, at 1 , col. 6 [hereinafter cited as Berman Losers].

89. Hedging is a technique developed by $A$. W. Jones to allow the investor to benefit from both upturns and downturns in the market by leveraging long as much as possible in the upswings and leveraging shorts in the downswings. An attempt is made to combine overvalued securities of low volatility in market upswings and high volatility in market downswings with undervalued securities of high volatility in market upswings and low volatility in market downswings. By so doing, risk may be reduced while al. lowing the investor to profit both from upswings and downswings.

For general information on the hedging technique and $A$. W. Jones, see Pracnsanc

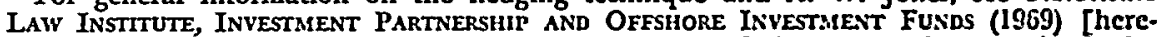
inafter cited as PLI, PARTNERSHIrs]; Berkowitz, Regulation of Hedge Funds, 2 SEGURITIES REG. 961 (Jan. 17, 1969) [hereinafter cited as Berkowitz, Hedge Funds]: Hawes, Hedge Funds-Investment Clubs for the Rich, 23 Bus. LAw. 570 (1968); Hedge Fund Miseries, Fortune, May 1971, at 269; Loomis, The Jones Nobody Keeps $v p$ w'ith, Fontune, April 1966, at 237 [hereinafter cited as Loomis, Jones]; Loomis, Hard Times Come to the Hedge Funds, ForTuNe, Jan. 1970, at 100 [hereinafter cited as Loomis, Hard Times]; M. Rieger, Hedge Funds-Prospects for Private Investment Parlnerships Emploging Specu. lative Techniques, 51 CHI. BAR REC. 469 (19\%0).

90. See note 85 supra.

91. Risk arbitrage is a technique developed during the 1960's when large numbers of corporate mergers were taking place. In order to bring about acceptance of the merger by the acquired firm, the acquiring firm would always have to offer higher than market prices for the shares of the acquired company. As a result, it was found that during merger negotiations which appeared to be successlul, the market price of the shares of the acquired company would rise slightly, while the price of the shares of the acquiring company would fall slightly. By highly leveraging shorts of the acquiring company and longs of the acquired company, a substantial profit could be made if the merger were achieved. See STAFF OF ANTrmust Subcomm. OF House Judiciari Coms., 920 Cong., Ist Sess., Investigation of Conglomernte Mercers 1-7, 195.99 (Comm. Print. 1971) [hereinafter cited as Conclomerate Investication]; G. Wyser-Pratte, Riss AnDiTRAGE (1971).

92. See note 6 supra.

93. Reports on the activities of certain skilled investors and investment managers indicate that pure short selling, risk arbitrage, and convertible hedging have been cmployed with enormous success. See Berman Losers, supra note 88; ConcLomenatr. INvestication, supra note 91, at 195.99; Thorp \& Kassouf, supra note 85, at 3, App. E. Thorp and Kassouf indicate that over a ten-year period the convertible arbitrage tech. nique was able to register, without exposure to risk, a gain before expenses of 700 percent. 
tions of the Company Act have been able to use these techniques to secure substantially better returns than those obtained by mutual funds.

The most specific information available concerns "hedge funds"limited investment partnerships composed of small groups of substantial investors employing sophisticated investment techniques. Hedge funds ${ }^{94}$ have succeeded in avoiding SEC regulation under the Company Act, ${ }^{95}$ and data collected by the SEC indicate that they have exploited their enhanced flexibility by engaging in borrowing and short selling much more heavily than the mutual funds. ${ }^{00}$

Data available on the $A$. W. Jones Fund, the largest of the hedge funds, indicate that it had returns far higher than the best mutual fund for each of the periods 1949-68, 1951-70, and 1961-70.97 Also, by judi-

94. See note 89 supra. Use of hedge funds is effectively limited to substantial investors by very high investment requirements-usually at least \$100,000. See Loomis, Jones, supra note 89; Loomis, Hard Times, supra note 89; 2 Institutionsl Study, supra note 6, at $290-91$.

95. The hedge funds have been able to avoid classification as investment companies for purposes of the Company Act and the Internal Revenuc Code by claiming to fit within the $\S 3(\mathrm{c})(1)$ exception of the Company Act, 15 U.S.C. $\S 80 \mathrm{a} \cdot 3(\mathrm{c})(1)$ (1970), since they are not making a public offering and have less than 100 shareholders. See 1LI, PAkTNERSHIPS, supra note 89 , at 319-20; pp. 1308-10 supra.

96. 2 INSTITUTIONAL STUDY, supra note 6, at 294-97. The portfolio manager of one mutual fund attempting to use the convertible arbitrage technique indicated that he found it almost impossible to operate under the SEC's leverage and short selling restrictions. He was continuing to operate one fund but was forced to terminate another becausc of SEC restrictions. Telephone Interview with J. L. Alliger, Investment Manager of Con. vertible Leverage Fund, Jan. 29, 1973. Another fund manager attempting to use shorting both in its pure form and as a risk-reducing mechanism found the SEC's short-sclling restrictions extremely burdensome. Telephone Intervicw with Peter Vlacuse, Investment Manager of Dreyfus Leverage Fund, Jan. 29, 1973.

97. A. W. Jones had an overall gain of approximately 4400 precent for the period 1949 . 68,2800 percent for the period 1951-70, and over 600 percent for the period 1961-70. Sec Prospectus of Hedged Investors, Inc. 5-7 (1968); Annual Report of A.W. Joncs Fund, March 30, 1970, on file at Yale Law Journal. The mutual funds for which data arc available with the highest returns over these periods had gains of approximately 2600 percent for the period 1949-68 (T. R. Price Fund); 1300 percent for the period 1951.70 (Dreyfus Fund), and 375 percent for the period 1961-70 (Fidelity Fund). See 14 FuND. SCOPE 63 (1971).

Jones was apparently able to achieve very stable performance Icvels, avoiding losses in two out of the three major market declines of the period. Therefore, in retrospect, it appears that for all periods but $1969-70$. Jones was able to maintain a fairly low risk level.

The data were compiled according to the same principles, with expenses deducted and all gains and dividends reinvested. In fact, the data are prejudiced in favor of the mutual funds in two ways: first, hedge funds have a much larger expense ratio than the average mutual fund. See 2 Insriturional STUDY, supra note 6, at 300.02. Sccond, the hedge fund's gain for the periods $1951-70$ and 1961-70 is computed only to April 30,1970 , while the mutual funds' gains are computed to December 31, thus taking into ac. count almost all of the 1970 decline in the hedge fund's performance and including all of the 1970 market rise in the mutual funds' performance. The market performance data for 1970 are contained in A. WIESENBERGER \& Co., INVESTMENT COMPANIES 1971, at 21 (1971).

Of course, such a performance comparison suffers from several weaknesses. First, it would be preferable to compare average mutual fund performance with average hedgc fund performance. However, sufficient data are not available for such purposes. Sccond, some leading academic authorities on mutual funds have recommended that performance 
cious use of short selling, A. W. Jones was able to avoid losses in the market decline of 1962 and even to make profits in the market decline of $1966 .{ }^{98}$ Using similar techniques, another hedge fund was able to avoid losses in the market decline of $1969-70 .^{90}$ In all these periods, mutual funds generally fared badly. ${ }^{100}$

The detrimental impact of the restrictions is further illustrated by the experience of a number of mutual funds known as "go-go funds," which were formed in the 1960's to seek the higher returns offered by high risk investment. ${ }^{101}$ After leveraging to Company Act limits, they purchased large amounts of very high risk securities. ${ }^{102}$ In the $1969-70$ market decline they lost heavily, ${ }^{103}$ and many came close to bankruptcy because of the illiquidity of their portfolios. ${ }^{104}$ While relaxation of the Company Act controls alone might not have altered this behavior, the

figures be adjusted to reflect degree of risk taken by a fund. See Friend \& Blumc, supra note 66, at 561. Presumably, the performance of Jones and of mutual funds would have to be similarly adjusted. Again, however, sufficient data are not available to do so. Finally, it is impossible to exclude all other variables, such as superior access to inside information and superior investment skill, and therefore impossible to render a conclusive judgment.

98. See Loomis, Jones, supra note 89 , at 247.

99. See Hedge Fund Miseries, Fortune, May 1971, at 209. The fund was Stcinhardt, Fine, \& Berkowitz.

100. For confirmation that mutual funds suffered large losses in the 1962, 1966, and 1969-70 market declines, see the charts of performance of 200 of the more significant funds in A. WIESENBERGER \& Co., INvestMENT CoMranies 195-361 (1963); id. at 137.264 (1967); id. at 145-306 (1971).

101. C.F.A. PorTFolio STUDY, supra note 57, at 61.76; Bicl, Imestment Problems and Prospects, Cos. Fin. Chr., June 12, 1969, at 1, col. 1; Bingham, Relative Performance-Nonsense, Fin. ANALysts J., July-Aug. 1966, at 101; Owens, Mlutual Funds and the "Letter Stock" Problem, Com. Fin. CHR., July 31, 1969, at 22, col. 1; The Sixties: Performance is no Longer a Dirty Word, ForBes, Jan. 1, 1970, at 223.

102. See 2 Instritutional STudy, supra note 6, at 284-85, 294.96.

It appears that hedge funds, in addition to borrowing more heavily than the go-go funds as would be expected from an efficiency analysis, also tended on the average to purchase the same categories of high risk stock. On the basis of an efficiency analysis of investments, several explanations for this behavior are possible. First, both the go-go funds and the hedge funds borrowed to their respectipe limits under the Company Act and Exchange Act restrictions and then, seeking still higher risk and return, added riskier stocks to their portfolios. See note 101 supra. Second, as a further explanation, both may have chosen to purchase the riskier securities because they vere capable of locating undervalued securities among them and, as a result, able to receive higher than expected returns for those levels of risk. There is empirical evidence that this explanation is correct in FrIEND STUDY, supra note 59, at 80-90. However. there is also evidence that such a strategy is no longer possible since the riskicr issues appear now to be overvalued. See Wall St. J., Jan. 26, 1973, at 1, col. 6. The historical evidence indicates that there will be periods when it is possible to locate undervalued risky securities and periods when it is not possible. See Friend \& Blume, supra note 66, at 570.71.

Whichever explanation is valid, it is clear that there will be periods when levernging will be a superior form of risk-taking, and that during those periods mutual funds may be forced into inefficient risk-taking at an earlier point than large, sophisticated inves. tors using unregulated vehicles such as hedge funds. See note 74 supra.

103. See Glenn, Some Swingers Found the Going Rough Last Ycar, B.ARrox's, Feb. 3, 1969, at 27, col. 2; Performance Funds: Under a Cloud, Fondes, Aug. 15, 1969, at 78, 80; Revolt Against the Funds, Fortune, Dec. 1971, at 165-65; Friend Study, supra note 59, at 144. See Wall St. J., Jan. 26, 1973, at 26, col. 2; Telephone Interview with Peter Vlacuse, Investment Manager of Dreyfus Leverage Fund, Jan. 29, 1973.

104. See Wall St. J., Jan. 26, 1973, at 26, col. 2. 
change would certainly have opened a more efficient means of risktaking.

Although this evidence is fragmentary, it does suggest, as would be expected from theoretical considerations, that the prevailing strict regulation can damage mutual funds' performance. The results of the SEC study that served as a foundation for the Company Act, which showed a positive correlation between poor performance and leverage for the period 1930-35, must have been either incorrect or peculiar to an anomalous period in economic history. ${ }^{105}$

\section{Conclusion}

The stricter controls on short selling and leveraging imposed on mutual funds undermine the goals they were designed to further. They do not act as an effective ceiling on risk-taking. Rather, they force mutual funds to take unnecessary risks in order to secure high returns. These controls may not be the only factor involved in the poor overall performance of the funds; but they are almost certainly a contributing cause. Thus, the controls needlessly frustrate the primary role that Congress envisioned for the funds-to provide the small investor with improved access to the high risks and returns of the securities markets. The most appropriate reform would be simply to repeal the restrictions now imposed by the Company Act and the Internal Revenue Code, ${ }^{100}$ and thus to treat mutual funds on a par with all other investors. ${ }^{107}$

105. See p. 1312 supra. There is evidence in the legislative history of the Company Act's restrictions on leverage that the SEC depended on outmoded business cycle thicory in reaching its findings on the effects of leverage. To the extent that this was the casc, the SEC's conclusions were invalid. See E. LERner, Readings in Financial. Analysis and Investment Management 69-118 (1963); National Bureau of Economic Research, Tile Business Cycle Today (V. Zarnowitz ed. 1972). There is also evidence in the legislative history that the period analyzed (1930-1985) may have been unusual in that the overall market decline was so sharp that interest rates actually exceeded the risk premium for investing in common stocks. See 2 TRUST STUdY, supra note 42, at 922.28; 1940 Senate Hearings, supra note 44 , at $1028-29$.

106. The specific motivation behind the tax penalty on short-term trading, including short selling, is not entirely clear. It is apparent, however, that the basic motivation was to implement the general purposes of the Company Act. See S. REP. No. 1775, 76th Cong., 3d Sess., 12 (1940); H.R. REP. No. 2393, 77th Cong., 2d Sess., 28 (1940). It would probably be best to eliminate the entire provision, since mere exemption of short sales from the penalcy would still leave mutual funds unable to engage in convertible arbitrage.

107. The alternative to repeal-strengthening the controls by adding restrictions on the riskiness of individual securities that a fund can buy-would be contrary to the equal opportunity goal of the Company Act, see pp. 1310.12 supra. 